\title{
Et bidrag til kundskab om stemningen i Holsten og Slesvig 1813.
}

Dèt er almindelig antaget, at stemningen hos den jærne befolkning både i Holsten og Slesvig var loyal mod Danmark indtil langt ind i dette århundrede, at den tyske frihedskrigs begejstring kun fandt genklang hos en forholdsvis ringe del af de mere dannede samfundsklasser. Der er imidlertid opbevaret enkelte træk, som tyder på, at der har reret nogen forskel mellem Holstenernes og Slesvigernes følelser. Her skal kun mindes om den modtagelse, som Dahlmanns tale ved Kiels universitets fest efter Waterlooslaget fik. Julie Hegewisch, som senere blev Dahlmanns hustru, skriver i et brev herom: „De slesrigske studenter lo, skar tænder, da han talte om broderforholdet mellem Slesvigere og Holstenere" (Springers „Dahlmann“, Graaes „U. J. Lornsen“ o. fl. st.) - Et andet bidrag til kundskab om datidens stemninger, som hidtil ikke har været kendt, er mig velvillig meddelt af hr. oberst Blom. Oberst Bloms fader, den bekendte militærforfatter Hans Jørgen Blom, var 1813 som ung løjtnant med i den danske hær, der søgte at forsvare Holsten mod Bernadottes tropper men måtte trække sig tilbage for overmagten; han forte i denne tid en dagbog, som endnu er til og er: i sonnen, oberst 0 . Bloms, værge. Et par ytringer i denne daghog riser, at han har folt sig släet af forskellen mellem Holstenernes og Slesvigernes følelser overfor Danmark; måske har det herved været af betydning, at de eyne, han 
kom mest i berøring med, hørte til den gamle gottorpske del af Holsten, der forst var bleven forenet med den kongelige del red mageskiftet 1773. De pågældende ytringer lyder således i oversættelse (dagbogen er ført på engelsk):

Omtrent \%. dec., efter træfningen red Bornhoved: „Fra denne hytte kom vi til en anden, hror vi bler modtagne så godt, som jeg ventede at blive modtagen i Holsten ".

- 9. dec.: Om formiddagen drog vi i en fart fra Russee, uden at ri kunde for at vide, hvad der var grunden til den hast, hrormed ri rykkede afsted. Vor march gik til Landwehr, hror ri skulde gå orer kanalen. Da jeg var kommen over broen, som fører orer lette vand, og som blev sat i brand, øjeblikkelig som ri var ovre den, var jeg glad ved at have forladt et land, hvor vore troppers storste anstrængelser blev mistydede (were mistaken), og hvor fí rar os hengivne, mange hadede os, og største delen var ligegyldige mod os. Jeg drog med gladerefølelse ind i et land, hror indbyggerne ikke holdt det for en skam at rære Danskere, og hror man så på vor fare med et deltagendeblik, og vor fremgang blev ledsaget af deres velsignelser."

Hvis andre skulde være $i$ stand til at give flere oplysninger om, hror vidt der virkelig har ræret denne modsætning i stemningen nord og syd for Ejderen og Kanalen, beder jeg ham sende dem enten til udgiverne af ,Sønderjydske Årbøger" eller til undertegnedle.

Joh an Ottosen. 